\title{
Sanín Cano, Maestro del Ensayo Breve
}

CeVive de su entusiasmo por la idea. Ella reverbera en todos sus
libros..."

"Sus ideas secundarias son muchas, luminosas, dinámicas, fascinadoras, pero no son contradictorias. Su inteligencia sabe conciliarlas todas y esa conciliación se hace posible porque las ideas fundamentales que rigen su vida y fomentan su actividad inverosímil a la edad de ochenta y cuatro años, están vivamente arraigadas en su alma y forman parte de su ser. En suma, la preponderancia de Jorge Brandes en el siglo de las abdicaciones, en un mundo que parece edificado con la premeditada intención de hacerlo servir de circo para los saltimbanquis de genio, es debida a su carácter."

Estos párrafos que hace más de veinte años consagró Sanín Cano a Jorge Brandes ¿̇no parecen, hasta en la alusión a la avanzada edad que entonces alcanzaba el insigne crítico danés, escritos para definir la personalidad del propio Sanín Cano, que simboliza en la América española un triple magisterio: el del saber, el de la cultura y el del carácter?

Porque si profundo es su saber, que presta autoridad a cuanto escribe; si vasta es su cultura, que le permite recorrer con arte e ingenio todos los campos de la inteligencia, lo que mejor define su personalidad es su carácter, su conducta rectora y limpia, su actitud de apóstol del pensamiento.

Durante su larga y fecunda vida, Baldomero Sanín Cano ha difundido, de modo incansable, a los cuatro vientos del espíritu, los tesoros que ha acumulado por obra del saber y la cultura. Su pluma ha sido estímulo y acicate a la curiosidad intelectual de la más selecta clase lectora de nuestra América, que no ha tenido mejor guía para mantenerse en contacto con el movimiento contemporáneo 
de las ideas. Dentro de tan vasto dominio, si un día aborda problemas de trascendencia social como la civilización manual, se adentra otro día en el campo de la historia para desarrollar observaciones tan ingeniosas y originales como las que le sugiere el descubrimiento de América en relación con la higiene; o analiza cuestiones de alta docencia en torno al espíritu nuevo y las universidades; o espiga con sereno juicio en las literaturas de todos los tiempos y todas las latitudes, y si hoy habla de Shakespeare o de fray Luis de León, mañana disertará sobre Galsworthy, Samuel Butler o Carducci, o sobre Marinetti, Ganivet, Brandes y Nietzsche.

No es un divulgador, sino un sagaz expositor que cuando aborda un tema es para dar a conocer conceptos originales. Nunca ha tratado un asunto si no es para exponer ideas propias y observaciones personales.

Es, por eso, un ensayista de primera fuerza. No hay ensayo digno de tal nombre cuya esencia no sea la exposición de conceptos y apreciaciones personales. Una monografía puede ser voluminosa y exhaustiva - valga el anglicanismo-; puede agotar el tema en todos sus aspectos, con lujo de erudición y conocimiento; pero valdrá menos, sin duda, que un ensayo de pocas páginas, si este ensayo atesora ideas originales. Hay monografías cuya importancia reside en un solo capítulo que contiene la aportación personal del autor: lo demás es información, que puede ser copiosa y útil, pero que nada nuevo agrega a la apreciación del tema, por cuanto repite 0 resume lo que ya está dicho en otros libros. Al buen ensayista le basta con escribir ese capítulo, que nos trae su mensaje, en vez de un libro: se limita a darnos su aportación personal y prescinde del de todo ese lastre de erudición, que mejor encaja en la misión del divulgador y está destinada a ilustrar lectores que no conocen la materia.

En el ensayo mismo suele ser necesaria o conveniente una introducción que recoja, en apretada síntesis, antecedentes, datos y apreciaciones generales sobre el asunto. El ensayo gana en brevedad y concisión si esa parte no se hace demasiado extensa, cuando no sea posible suprimirla; y así llegamos al ensayo breve, comprimido, mínimo si se quiere, de pocas pero jugosas páginas, pletóricas de fuerza original. 
En esta clase de ensayo sobresale Baldomero Sanin Cano. Como desecha toda digresión innecesaria y descarta la hojarasca, cuatro, seis $\mathfrak{u}$ ocho páginas le bastan para concentrar una apreciación propia, profunda y certera. Mucho se ha escrito sobre George Bernard Shaw: pocos han dicho tanto sobre él como Sanín Cano en su brevisimo ensayo "Bernard Shaw y el sentido común", en el cual advierte que la clave de la personalidad de Shaw estriba en que, por lo general, se atiene al sentido común.

Al hablar de John Galsworthy sintetiza en pocas palabras un aspecto característico de su obra: la ausencia de un sentido jubiloso de la vida, lo que más que pesimismo, es seco desasimiento de toda visión amable de las cosas. "Galsworthy - dice-, casi ha suprimido la alegría en su representación de la vida, tal como él la entiende. No quiere decir que carezca de humor, porque sin ese elemento, la levadura del pensamiento y de la emoción, apenas hay artista que logre fijar aspectos de la vida moderna en una forma durable. Pero la manera de ver al hombre carece en Galsworthy de la nota regocijada."

Primor de síntesis es la forma en que Sanín Cano resume la personalidad de Guillermo Valencia, en quien, proclama, "predomina lo espiritual, predomina su noción filosófica de la vida, que trata de abarcar todas las ideas y vaciarlas en los moldes de su propia sensibilidad". Y, refiriéndose a su obra poética, agrega : "Parece parnasiano porque en la forma y en el contenido estos poetas dejaron huella perdurable y su ejemplo es un valor adquirido de que no podrá el hombre desprenderse. Tiene lampos románticos su hechura, porque el romanticismo no fué moda pasajera sino una renovación, de tan hondo alcance y tan significativa extensión, que produjo en el espíritu humano transformaciones perdurables como las religiones y las filosofías. Tomó Valencia de los impresionistas cuanto en esa doctrina vale en el sentido de aproximación a la naturaleza y de ensayo de representación inmediata de las apariencias. De los simbolistas captó la verdad trascendente, la enseñanza de que la palabra es un símbolo y de que el lenguaje nació, ha crecido y se desenvuelve porque el hombre tiene la capacidad divina de transformar las apariencias en símbolos. Toda su poesía es espíritu y, como él mismo lo ha dicho comentando èl aforismo de Nietzsche, 
escribe con sangre porque la sangre es la mejor expresión del espíritu."

Cuatro compilaciones de ensayos breves ha publicado Sanin Cano, aunque ha escrito mucho más: La civilización manual y otros ensayos (1925), Indagaciones e imágenes (1926), Crítica $y$ arte (1932), Ensayos (1942) y Divagaciones filológicas y apólogos literarios (1934). A estos cinco libros se agrega un volumen, el último que ha publicado, sobre las Letras colombianas (1944) que aunque surgido de un propósito didáctico, pues resume un curso de historia literaria, es un conjunto de ensayos comprimidos sobre las figuras más conocidas de la literatura de su país. Difícil es definir en escasos párrafos, como él lo hace, los aspectos esenciales de la vida y la obra de los autores que enjuicia de modo tan certero, $\mathfrak{u}$ ofrecer de igual suerte una visión de conjunto de movimientos literarios como el modernismo.

Ese libro, avalorado por el fino sentido crítico de Sanín Cano, es un nuevo testimonio, y no el menos elocuente, de las cualidades excepcionales que lo consagran como maestro del ensayo breve.

Max Henríquez Ureña 